Tyndale Bulletin 66.1 (2015) 153-156

\title{
REPETITION IN HEBREWS ${ }^{1}$
}

\author{
Nicholas J. Moore \\ (nicholas.moore@magd.oxon.org)
}

The phrase 'vaine repeticions' indicts medieval Roman Catholic worship in Cranmer's preface to the 1549 prayer book, and recurs in the Geneva and King James Bibles to describe the prattling prayers of the Gentiles in Matthew 6:7. These examples indicate both the bad press repetition has had in certain streams of theological tradition, and the ambivalence of such a reception: Cranmer's liturgy was to be repeated daily throughout England, and Matthew 6:7 forms part of the introduction to the most repeated petition in Christian history, the Lord's Prayer. This reception has in part been caused by and has in turn affected readings of the Letter to the Hebrews, which speaks of repetition in ways unique in the NT and has often been assumed to denigrate repetition as negative, ineffective, and ritualistic. This study challenges this reading, demonstrating that repetition functions in a multivalent way in the letter. The study thus rehabilitates our understanding of repetition in Hebrews, and thereby lays foundations for the theological development and deployment of this theme in other contexts.

In Part One the question of repetition in Hebrews is approached from three different angles: modern scholarship; relevant texts and traditions extant in the first century $\mathrm{AD}$; and early Christian texts which draw on Hebrews in relation to questions involving repetition. In Hebrews scholarship repetition has received insufficient critical examination, and it has been assumed both that repetition impedes efficacy and also that such an association is self-evident. In fact, repetition should not automatically be associated with ritual (not all repetition constitutes ritual, and not all rituals are repeated) and it can have a range of effects, both positive and negative.

1 Nicholas J. Moore, “"Not to Offer Himself Again and Again”: An Exegetical and Theological Study of Repetition in the Letter to the Hebrews' (D.Phil. thesis, University of Oxford, 2014). Supervisor: Prof. M. Bockmuehl. 
Through an examination of notions of repetition and singularity in a number of representative texts from the Old Testament, Qumran, Middle Platonism, and early Christianity, it is seen that Hebrews' discussion of repetition is distinctive in its first-century settings. In particular, the idea that the very repetition of tabernacle/temple sacrifices shows that they did not work is not found elsewhere either in contemporary Judaism or in early Christianity, making an account of the meaning and function of Hebrews' argument concerning repeated sacrifices all the more necessary. A combination of singularity motifs associated with the Day of Atonement and early Christian crucifixion traditions best accounts for Hebrews' development of themes of singularity and repetition.

The early reception of Hebrews' deployment of repetition in relation to a variety of issues - a second repentance, sects which practised frequent baptisms, Christian failure to offer animal sacrifices, and the eucharist-highlights both the appeal of the singularity and uniqueness of Jesus' death, and some problems which arise when Hebrews' treatment of repetition is transferred to other contexts.

Part Two constitutes the exegetical core of the thesis, and considers in turn the three areas of Hebrews in which repetition plays a role: the repetition of God's speech in the exordium and in use of the OT throughout the letter; the repetition of repentance, primarily in 5:116:12 and additionally in 10:26-31 and 12:16-17; repetition of sacrifices in contrast to the once-for-all sacrifice of Christ in 7:23-28 and 9:110:18.

Repetition of divine speech in the old covenant manifests God's graciousness rather than indicating the imperfection of old covenant revelation. This plurality prepares for and is in continuity with, not in contrast to, God's word through his Son. It continues into the new covenant in the words brought by the community's leaders (including the author of the letter) through the OT and the tradition about Jesus. Hebrews does not regard this plurality as merely a fact which must be accommodated, but instead exploits it in order to bring to light the way in which the scriptures proclaim the temporary nature of the old dispensation and the eschatological realities which have now come. That is to say, plurality is essential to the way in which Hebrews reads and uses scripture.

When it comes to repentance, Hebrews portrays this as a turn from a state of complete unbelief, based on the singular and unrepeatable 
atonement provided in Christ, and utilizes the concept of recrucifixion to express the utter horror of apostasy. Early evidence for the recrucifixion motif in the Quo vadis scene of the Acts of Peter and in Origen supports the presence of this notion in Hebrews 6. The impossibility of repeating the atonement entails the impossibility of repeating repentance following apostasy. Yet at the same time Hebrews promotes forms of repeated and ongoing practice that sustain Christian life. Such repetition emerges as fundamental for sustaining perseverance.

Repetition has greatest prominence in the letter's discussion of the Levitical sacrificial system. The Levitical priesthood is characterized by plurality as a result of the weakness and mortality of its priests. Similarly, animal sacrifices are inherently incapable of cleansing the conscience because they represent heavenly and eschatological realities rather than effecting them. Thus in both cases repetition indicates inefficacy, but does not cause it; rather, it reveals a weakness whose source is elsewhere. This indicative function of repetition relates to the essentially eschatological and christological nature of Hebrews' argument: the weakness of the old covenant and its divinely-intended transitory nature are understood fully only in the light of Christ's coming. Hence repetition takes on a negative connotation only where it is contrasted with the singularity of Christ's priesthood or sacrifice.

Where repetition is not contrasted directly with Christ, such negative connotations do not obtain. Especially notable in this regard is Hebrews 9:6, where the continual entrance of the priests into the first tent of the tabernacle must be understood positively in order for the contrast with the restricted access of the high priest's once-yearly entrance into the second tent to work. The extended qal wahomer with Christ (9:11-14 building on vv. 1-10) demonstrates that he unites two things which were represented by different parts of the tabernacle system: the high priest's access to the most holy place and the ordinary priests' continuous service. This juxtaposition of the once-for-all and the perpetual is combined and fulfilled in Christ's unique sacrifice and the ongoing heavenly access and intercession it inaugurates. Thus the motif of the singular atonement does not operate in simple opposition to repetition; rather, it relates to continuity and eternity, and is therefore developed at times in contrast to and at times in correspondence with repetition. Accordingly, the repeated activity of Christians is properly described as cultic: Hebrews encourages its audience that they have a 
sanctuary in which God dwells and a high priest through whom they can approach him; they offer real sacrifices of praise at the times of the heavenly temple service, in continuity with and extension of its worship.

The thesis concludes by summarizing the different kinds of repetition evidenced in Hebrews and grouping them into two categories according to whether the repetition of a particular thing conflicts with or serves to appropriate the atoning work of Christ. The study thus provides a reappraisal of the function of repetition in Hebrews, countering a tradition of reading this phenomenon uniformly and negatively. This reappraisal indicates that the significance of Hebrews for repetition in Christian tradition needs to be revisited: the tension between repetition and singularity is productive and indeed fundamental to the Christian life, and is epitomised in the two dominical sacraments. 